\title{
The languages spoken in the water body (or the biological role of cyanobacterial toxins)
}

\author{
Aaron Kaplan ${ }^{1}$, Moshe Harel ${ }^{1}$, Ruth N. Kaplan-Levy ${ }^{2}$, Ora Hadas ${ }^{2}$, Assaf Sukenik ${ }^{2}$ and Elke Dittmann ${ }^{3}$ \\ 1 Department of Plant and Environmental Sciences, The Hebrew University of Jerusalem, Jerusalem, Israel \\ ${ }^{2}$ The Yigal Allon Kinneret Limnological Laboratory, Israel Oceanographic and Limnological Research, Migdal, Israel \\ ${ }^{3}$ Institut für Biochemie und Biologie, Universität Potsdam, Potsdam, Germany
}

Edited by:

George S. Bulleriahn, Bowling Green

State University, USA

\section{Reviewed by:}

Michael R. Twiss, Clarkson University, USA

Greg Boyer, State University of New York, USA

\section{${ }^{*}$ Correspondence:}

Aaron Kaplan, Department of Plant and Environmental Sciences, The

Hebrew University of Jerusalem,

Edmond J. Safra Campus, Givat Ram,

Jerusalem 91904, Israel.

e-mail:aaron.kaplan@mail.huji.ac.il
Although intensification of toxic cyanobacterial blooms over the last decade is a matter of growing concern due to bloom impact on water quality, the biological role of most of the toxins produced is not known. In this critical review we focus primarily on the biological role of two toxins, microcystins and cylindrospermopsin, in inter- and intra-species communication and in nutrient acquisition. We examine the experimental evidence supporting some of the dogmas in the field and raise several open questions to be dealt with in future research. We do not discuss the health and environmental implications of toxin presence in the water body.

\section{Keywords: aoa, cylindrospermopsin, microcystin, cyr, mcy}

\section{INTRODUCTION}

"What determines who is there?" is a long standing but nevertheless intriguing biological/environmental question. Numerous field and laboratory studies, and modeling of the data thereof, were performed in an attempt to reveal the effects of biotic and abiotic parameters on the temporal and spatial dynamics of phytoplankton populations (Ogawa, 1988; Walsby, 1997; Abraham, 1998). There is a growing body of evidence that secondary metabolites play an important part in the shaping of the community composition through inter- and intra-species communication but, for the most part, their biological role, mode of action, and regulation of their production are poorly understood. One example is the evolutionary drivers for the richness and large diversity of secondary metabolites produced by various cyanobacteria, a phenomenon that we know little about. It has been proposed that at least part of the richness observed in the case of a Lyngbya $\mathrm{sp}$. is due to improper systematic analysis and that several strains are in fact involved (Engene et al., 2011) but, if any, this argument strengthens the message that a large diversity of secondary metabolites is formed in this genus (Liu and Rein, 2010). A comprehensive chemotyping, i.e., analysis of the array of secondary metabolites within a given organism (Sivonen, 2008), combined with the application of genetic approaches using various genomic tools are required and to some extent emerging (Mejean et al., 2010; Jones et al., 2011). In the long run it will provide us with a complete array of metabolites produced and enable recognition of the genetic potential and its expression particularly under changing environmental conditions.

Cyanobacteria are known to produce a wide variety of secondary metabolites including non-ribosomally made peptides, polyketides, and alkaloids. Naturally most of the research on cyanobacterial secondary metabolites focused on those that were classified as toxic to eukaryotes, mainly microcystin, nodularin, saxitoxin, and cylindrospermopsin (Pearson et al., 2010), since their presence may constitute a serious threat to water quality in many freshwater bodies worldwide (Carmichael, 1997; Griffiths and Saker, 2003; Zegura et al., 2011). There is a growing body of evidence that regional and global climatic change may benefit various species of harmful cyanobacteria by increasing their growth rates, dominance, persistence, geographic distributions, and activity (see Paerl and Huisman, 2009; Sukenik et al., this issue).

Numerous publications have described the implications of cyanobacterial toxin production on environmental and health aspects but this is beyond the scope of the present paper. Here we discuss the nature and biological role of two cyanobacterial toxins, microcystin and cylindrospermopsin, for which experimentally based information has recently been obtained.

\section{MICROCYSTIN OCCURRENCE AND TOXICITY}

Microcystins are the most frequently reported cyanobacterial toxins in freshwater environments and are regarded as a major health hazard and challenge to the quality of drinking water (Dittmann and Wiegand, 2006). Microcystins are predominantly produced by freshwater strains including Microcystis, Planktothrix, and Anabaena (Welker and von Dohren, 2006) but were also incidentally reported from terrestrial environments. Toxic and non-toxic strains usually co-exist in natural bloom samples due to the sporadic distribution of toxin biosynthesis genes in the producing genera (Via-Ordorika et al., 2004). Microcystin penetrates the liver where it inhibits eukaryotic protein phosphatases type 1 and 2A, eventually leading to liver hemorrhage and death (Runnegar et al., 1995). The hepatotoxin was implicated in a number of animal and human intoxications, the 
most fatal case being reported from a hemodialysis center in Brazil where patients died with symptoms of hepatotoxicity after exposure to water from a nearby reservoir contaminated with cyanobacteria (Jochimsen et al., 1998). The cyclic heptapeptide displays the general structure $c y c l o(\mathrm{D}-\mathrm{Ala}-\mathrm{X}-\mathrm{D}-\mathrm{MeAsp}-\mathrm{Z}$-Adda$D-G l u-M d h A$ ) in which $X$ and $Z$ represent variable $L$ amino acids. $\mathrm{D}$-MeAsp is $\mathrm{D}$-erythro- $\beta$-methyl-aspartic acid, MdhA is $N$-methyldehydroalanine and Adda is $(2 S, 3 S, 8 S, 9 S)$-3-amino-9methoxy-2,6,8-trimethyl-10-phenyldeca-4,6 dienoic acid (Botes et al., 1984). Many variants have been described in the scientific literature, mostly differing in amino acid positions $\mathrm{X}$ and Z (Sivonen and Jones, 1999; Welker and von Dohren, 2006). The related nodularins are exclusively produced by Nodularia strains in brackish water environments and possess the general structure cyclo(D-MeAsp-L-arginine-Adda-D-Glu-Mdhb), in which Mdhb is 2-(methylamino)-2-dehydrobutyric acid (Annila et al., 1996).

\section{PHYSIOLOGICAL STUDIES ON MICROCYSTIN PRODUCTION}

Research toward an understanding of the biological role of microcystin started in the 1980s when several research groups began to study the impact of environmental factors on the cellular toxin content. Generally, the production of microcystin by a single strain seems to be rather consistent with variations usually not exceeding a factor of four (Sivonen and Jones, 1999). This led to the general notion that microcystin production is directly correlated to growth, perhaps showing a linear correlation between cell division and toxin production (Orr and Jones, 1998). This was further examined by the development of a model for the prediction of cellular microcystin contents from growth rates in $\mathrm{N}$-limited cultures (Long et al., 2001). This model is in agreement with data obtained in several studies that have reported high microcystin production rates in cultures with high nitrogen and high phosphorus concentrations that are not limited in growth (Sivonen et al., 1990; Vezie et al., 2002). From their data, Orr and Jones (1998) concluded that microcystin is not a secondary metabolite but rather displays attributes of an essential intracellular compound. The fact that microcystin and many other cyanobacterial "secondary metabolites" are produced from the beginning of the logarithmic phase indeed distinguishes them from secondary metabolites of many other microorganisms.

However, a number of other studies have reported effects of specific environmental factors on microcystin production. Lukac and Aegerter (1993) correlated low iron concentrations with an increased toxin production, whereas Utkilen and Gjolme (1992), detected higher microcystin production at high iron conditions. Other authors have suggested the impact of light, temperature, and pH (Vanderwesthuizen and Eloff, 1985; Rapala et al., 1997; Wiedner et al., 2003). Interestingly, some of the environmental factors had a differential effect on various isoforms of the toxin (Rapala et al., 1997). Many of the observed effects on microcystin formation might be due to a limiting response of growth to the respective parameter. The largest problem for the interpretation and comparison of the different studies, however, is the observed strain-specific difference in toxin production under standard growth conditions. The environmentally induced changes are far less pronounced than the differences in toxin contents measured in individual strains. Physiological studies could thus provide an overview about the influence of abiotic factors on microcystin production but could not provide a clue about the role of the toxin in the producing cells.

\section{BIOSYNTHESIS, REGULATION, AND EVOLUTION OF MICROCYSTIN}

A new era of research toward understanding the biological role of microcystin became possible with the identification of the mcy genes encoding the non-ribosomal complex for microcystin biosynthesis. The $m c y$ clusters were first described for two strains of Microcystis aeruginosa (Nishizawa et al., 1999, 2000; Tillett et al., 2000). The genomic locus in Microcystis spans $55 \mathrm{~kb}$ and comprises 10 bidirectionally organized genes encoding non-ribosomal peptide synthetases (NRPS), polyketide-synthases (PKS), tailoring enzymes, and an ABC transporter (McyA-J; Nishizawa et al., 1999, 2000; Tillett et al., 2000). The $m c y$ gene cluster was later also characterized for Planktothrix and Anabaena (Christiansen et al., 2003; Rouhiainen et al., 2004), a closely related gene cluster that could be assigned to the biosynthesis of nodularin in Nodularia (Moffitt and Neilan, 2004).

Knowledge about the biosynthesis gene cluster ultimately permitted analysis of the impact of environmental stimuli on the transcription of the mcy genes and a possible interaction of the promoter region with transcription factors. Several studies revealed a clear impact of light and iron-limiting conditions on mcy transcript abundance. Kaebernick and co-workers used the RNAse protection assay to quantify $m c y$ transcripts under various light intensities and qualities. They observed that mcy transcripts are elevated above a critical threshold of light of about $30 \mu \mathrm{mol}$ photons $\mathrm{m}^{-2} \mathrm{~s}^{-1}$ (Kaebernick et al., 2000). In a followup study, the authors could show alternative transcriptional start sites for the $m c y A-C$ and $m c y D-J$ operons in Microcystis under low light and high light conditions, respectively (Kaebernick et al., 2002). An increased mcy transcript accumulation under high light conditions was also found in Planktothrix agardhii (Tonk et al., 2005). A significant rise in the mcy transcript accumulation and an increased toxin production was observed following iron starvation (Sevilla et al., 2008). In contrast, the effect of light on transcription could not be correlated with higher toxin content per cell. Studies on the transcription of $m c y$ genes were thus not only answering questions but also raising new ones. For example, differential effects on the transcription of various $m c y$ genes were observed following various stresses such as oxidative stress. The $m c y \mathrm{~B}$ was only $20 \%$ up-regulated whereas $m c y \mathrm{~A}$, $m c y \mathrm{H}$, and $m c y \mathrm{D}$ transcripts increased by 270,330 , and $370 \%$, respectively, in agreement with published data (Straub et al., 2011).

Screening of the 750-bp long bidirectional mcy promoter region between $m c y \mathrm{~A}$ and $m c y \mathrm{D}$ revealed the presence of transcription factor binding sites for the ferric uptake regulator Fur and the global nitrogen regulator NtcA (Kaebernick et al., 2002). For both factors, binding to the mcy promoter region could be confirmed in vitro (Martin-Luna et al., 2006; Ginn et al., 2010; Figure 1). The Fur binding suggests a response of $m c y$ genes to iron availability and redox status of the cell, which could explain the effects of high light and iron-limiting conditions on transcript abundance. On the other hand, NtcA binding typically mediates a response of cyanobacterial cells to nitrogen-limiting conditions 


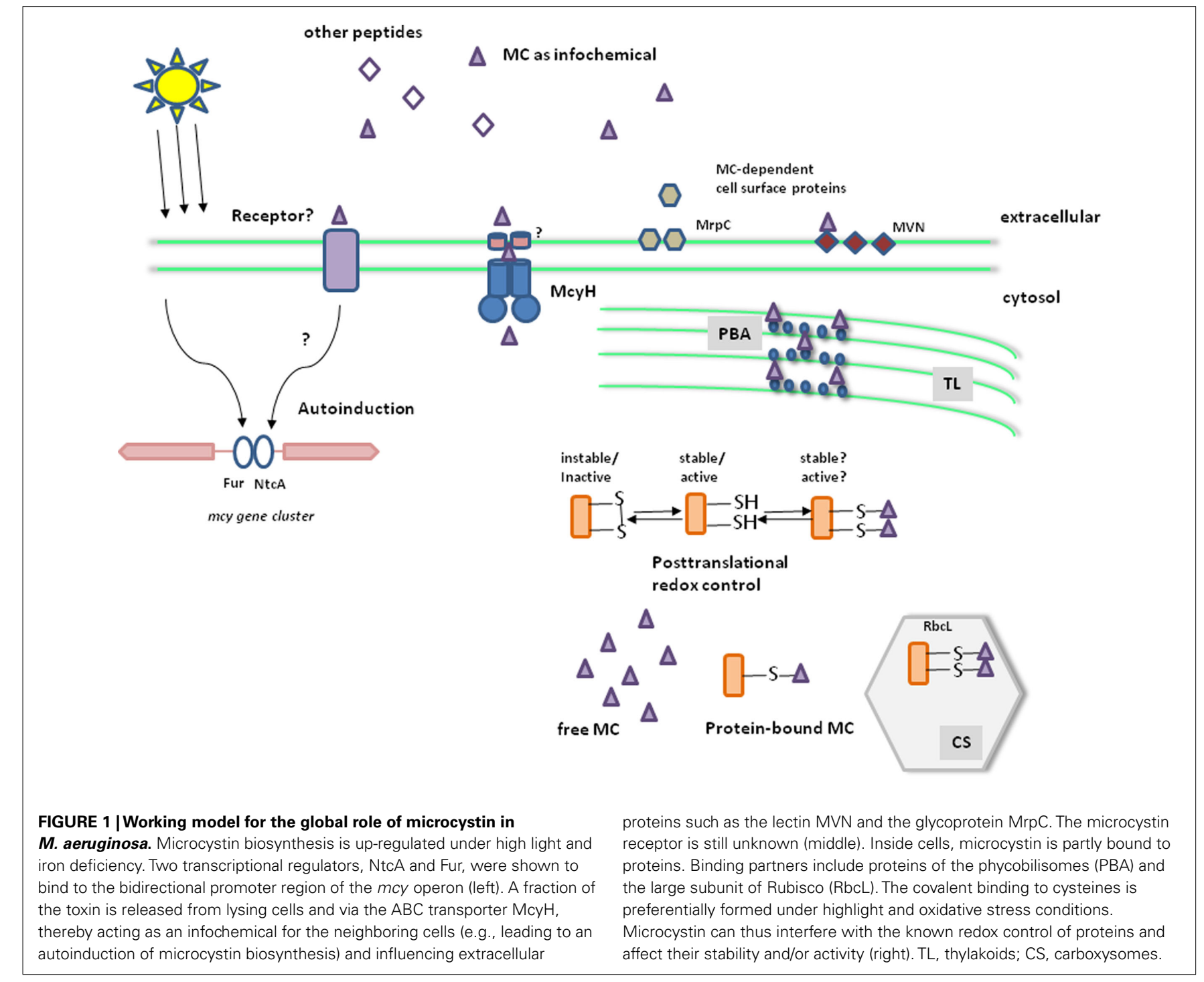

but the expected transcriptional changes (under different nitrogen concentrations) could not be confirmed (Sevilla et al., 2010). Considering the fact that the cellular redox state influences NtcA expression (Alfonso et al., 2001) and that NtcA and Fur regulons have been previously shown to overlap in cyanobacteria (LopezGomollon et al., 2007), NtcA binding to the mcy promoter region may reflect the dependence of mcy transcription on the redox status of the cell rather than on nitrogen availability.

Elucidation of mcy genes in different genera also provided a basis for the reconstruction of the evolutionary history of these genes. Whereas the sporadic distribution of genes suggested an impact of horizontal gene transfer on mcy evolution, the comparison of $m c y$ genes from various cyanobacterial genera with house-keeping genes could clearly rule out the possibility of a lateral transfer between different cyanobacterial genera. An evolutionary scenario has been proposed in which the ancestral mcy genes were already present in the last common ancestor of all present-day cyanobacteria (Rantala et al., 2004). The sporadic distribution was explained as a result of frequent gene losses. This hypothesis is supported by the observation of ongoing deletion events of partial or complete $m c y$ gene clusters in natural and laboratory populations (Schatz et al., 2005; Christiansen et al., 2008). Prior to the phylogenetic analysis and related data showing dynamic changes in the mcy genes, a major role of microcystin as a feeding deterrent was widely accepted. However, since the last ancestor of all extant cyanobacteria preceded the appearance of the metazoans, a primary defense role of microcystin against eukaryote grazers is questionable. It was recently demonstrated that microcystin binds to thiol groups of various proteins (Zilliges et al., 2011; see below) similarly to its binding to certain eukaryotic protein phosphatases. It seems likely that the toxic effect of microcystin (due to inhibition of these phosphatases) reflects a recent evolution of these proteins rather than its primary role. In this respect it is worth mentioning that a recent bioinformatic study suggested that the sxt genes encoding saxitoxin, a cyanobacterial neurotoxin, are also ancient and that potassium rather than sodium channels was the original target of this toxin (Murray et al., 2011). 


\section{COMPARATIVE ANALYSIS OF M. AERUGINOSA AND MICROCYSTIN-DEFICIENT MUTANTS}

As mentioned above, strain-specific differences in the rate of microcystin production are a major problem for the interpretation and comparison of studies on the impact of environmental stimuli. Moreover, comparative growth or feeding assays with toxic and non-toxic strains are biased by other strain-specific differences in addition to toxicity. The elucidation of microcystin biosynthesis genes provided the possibility to construct mutants that are deficient in microcystin production, but otherwise identical to the corresponding wild-type strains (Dittmann et al., 1997). The use of these mutants in comparative studies has significantly advanced our understanding about the biological role of microcystin.

The microcystin-deficient mutant $\Delta m c y \mathrm{~B}$ and the corresponding wild-type strain were used in feeding studies with Daphnia. These studies revealed that different Daphnia sp. could not distinguish between the wild-type and the microcystin-deficient mutant; both strains were ingested in similar rates (Rohrlack et al., 1999, 2001). These finding argued against a primary role as feeding deterrent as was widely accepted at the time. Wild-type and mutant were also compared for their growth and pigmentation under different light regimes (Hesse et al., 2001). The growth rates of the mutant and the WT were similar when grown at light intensities of 4-110 $\mu \mathrm{mol}$ photons $\mathrm{m}^{-2} \mathrm{~s}^{-1}$ but the absorption spectra in the range of photosynthetic active radiance varied significantly. The mutant cells possessed lower contents of chlorophyll a and of several carotenoids under these conditions (Hesse et al., 2001). Furthermore, a lower capability of mutant $\Delta m c y$ B to acclimate to low inorganic carbon concentrations was proposed (Jahnichen et al., 2007). These results were supported by growth competition studies using $M$. aeruginosa PCC7806 and mutant $\Delta m c y B$. The microcystin-producing wild-type had a strong selective advantage under low $\mathrm{CO}_{2}$ conditions (Van de Waal et al., 2011). A spontaneous Microcystis mutant, strain MG-J, bearing a deletion in mcy and unable to produce microcystins was isolated from a toxic wild-type strain MG-K (Schatz et al., 2005). Laboratory and field experiments comparing the wild-type with this spontaneous mutant indicated an advantage of the toxic strain over its non-toxic successor. When grown separated by a membrane, which allowed passage of the media but not the cells, MG-K severely inhibited the growth of MG-J. In addition, when MG strains were placed in dialysis bags in Lake Kinneret (Sea of Galilee), Israel, during the season in which Microcystis is often observed, cells of MG-J lysed but not MG-K (Schatz et al., 2005). Taken together, the data support the notion that microcystins play an important physiological role in the producing strains.

This, however, is difficult to accommodate with the observation that under natural conditions non-toxic colonies are present, sometimes in large proportion, together with toxic ones. What determines the proportion of microcystins-producing-cells in the natural Microcystis population is not clear. A thorough direct analysis of single colonies revealed that most of the colonies in the examined lake did not produce microcystins (Fastner et al., 2001).

\section{TOWARD CLARIFICATION OF THE MECHANISTIC ROLE OF MICROCYSTIN-EXTRACELLULAR ROLE}

The availability of the microcystin-deficient mutant also offered the possibility for a more detailed analysis of the role of microcystin at the molecular level. Proteomic comparisons between wild-type and mutant strains revealed the differential accumulation of a prominent protein spot. The protein identified by a reverse genetic approach was designated MrpA (microcystinrelated protein A) and shows some similarity to the RhiA protein of the symbiotic strain Rhizobium leguminosarum biovar viciae (Dittmann et al., 2001). Moreover, the mrpA gene was cotranscribed with a second gene, $\operatorname{mrpB}$ that codes for a protein with high similarity to the RhiB protein encoded as part of the same rhiABC operon (Dittmann et al., 2001). The Rhi proteins were implicated in symbiotic nodule formation. Interestingly, the operon is under the control of extracellular acylhomoserine lactone (AHL) type signals in Rhizobium (Rodelas et al., 1999). This raised the possibility of a role of microcystin as an intercellular signal. Indeed, microcystin is released from Microcystis cells, in particular above a critical light threshold (Wiedner et al., 2003). Transport of microcystin through the inner membrane might be mediated by the activity of $\mathrm{McyH}$, which shows homology to $\mathrm{ABC}$ transporter (Figure 1). A knock-out of the corresponding gene $m c y H$, however, leads to a complete loss of toxin production (Pearson et al., 2004) and thus the mutant could not be used to study the impact of $\mathrm{McyH}$ on internal microcystin level or assess a specific role in sensing of extracellular microcystin.

A possible extracellular role could nevertheless be assessed by an external addition of microcystin. Schatz et al. (2007) could show that addition of supernatants from cells lysed either mechanically or because of stress conditions leads to a strong upregulation of microcystin biosynthesis genes in the remaining cells. A less pronounced autoinduction effect could also be seen after addition of pure microcystin or other peptides, micropeptin, and microginin, produced by Microcystis which, together with microcystin, formed the stronger effect of the cell-free supernatant. Noticeably, the response of the remaining cells is strongly affected by the age of the culture but was hardly detected in older cultures. Analysis of the abundance of $m c y$ transcripts clearly indicated a large accumulation at stationary phase thereby reducing the response to externally provided microcystin. On the other hand, mcy transcripts were hardly detected in cultures maintained in early log phase for several generations, but these cells responded strongly to the addition of microcystins or the cell-free supernatant by upregulating the expression of $m c y$ genes. It was therefore suggested that microcystins serve as infochemicals; their release to the media by lysing cells due to various stressors is sensed by the rest of the Microcystis cells which upregulate mcy transcription (Figure 1; Schatz et al., 2007). Larger production of microcystin may promote the fitness of the Microcystis cells and their competitiveness with other phytoplankton species (reviewed by Pflugmacher, 2002; Babica et al., 2006).

Furthermore, several studies have supported a microcystin role in Microcystis colony formation. The expression pattern of two extracellular proteins, the lectin MVN (Kehr et al., 2006) and the glycoprotein MrpC (Zilliges et al., 2008) were strongly altered in 
mutant strains lacking microcystin. MrpC is the dominant extracellular protein in Microcystis and directly implicated in cell-cell contacts between Microcystis cells (Zilliges et al., 2008). Both MVN and $\mathrm{MrpC}$ seem to be specific for certain Microcystis ecotypes. It is not clear yet, if microcystin is directly involved in morphotype formation and the mechanism whereby it influences the cell surface proteins (Figure 1).

\section{EXPERIMENTAL SUPPORT FOR AN INTRACELLULAR ROLE OF MICROCYSTIN}

As indicated, physiological experiments using wild-type and mutants suggested that the ability to produce microcystin is beneficial for the Microcystis cells. Elucidation of the M. aeruginosa PCC7806 genome enabled a more comprehensive analysis of molecular differences between wild-type and microcystin-deficient mutant such as via proteomic comparisons in cells maintained under various conditions such as high light and darkness (Zilliges et al., 2011). Remarkably, under all the conditions examined loss of microcystin led to considerable alteration in the protein pattern. Noticeably, a large number of spots could be assigned to CalvinBenson cycle proteins, the phycobilisome, to redox-dependent reductases, and unidentified proteins (Zilliges et al., 2011). In particular, the differences in protein isoform formation were striking. Generally, the wild-type showed more protein isoforms than the microcystin-deficient mutant (Zilliges et al., 2011). In addition, it was shown that microcystin binds covalently to many of the differentially accumulating proteins in vitro and in vivo including phycobilisome antennae proteins and RbcL, the large subunit of Rubisco. This may at least partly explain the additional isoforms for proteins in the microcystin-producing wild-type (Figure 1; Zilliges et al., 2011) and the change in pigmentation during growth experiments (Hesse et al., 2001). Microcystin attachment to proteins was strongly enhanced under high light and oxidative stress conditions, raising the possibility of a consequent effect on their activity and stability. Many of the differentially accumulating proteins are indeed "cysteine-sensitive," i.e., subject to degradation upon oxidation of their cysteines following oxidative stress. A stabilizing effect of the microcystin binding was confirmed in the case of RbcL that was clearly more resistant to protease digestion in the wild-type (Zilliges et al., 2011). Moreover, growth experiments performed under oxidative stress or very high light conditions revealed a clear advantage for the microcystin-producing wildtype (Zilliges et al., 2011) and electron microscopy showed the localization of microcystin in the thylakoid and carboxysome areas (Gerbersdorf, 2006). These data may explain the differences in pigmentation and adaptation to low inorganic carbon concentrations discussed above and explain some of the controversial issues in earlier physiological studies. The fact that high light conditions lead to an increase in mcy transcription but not microcystin production is likely due to strong bias in microcystin detection due to covalent binding to proteins.

Another proteomic study revealed similar differences in the protein patterns between six different natural toxic and non-toxic strains, particularly in nine spots differentially accumulated in all toxic strains. Those were assigned to carbon-nitrogen metabolism and redox maintenance (Alexova et al., 2011). Differences in the acclimation to changing redox or light or carbon conditions may therefore be the main biotic parameters distinguishing toxic from non-toxic strains. This is at least partly supported by growth experiments that revealed an advantage of natural toxic over non-toxic strains under low (Schatz et al., 2005) but not under high carbon concentrations (Van de Waal et al., 2011), and an advantage of toxic strains under elevated temperatures (Dziallas and Grossart, 2011).

\section{CYLINDROSPERMOPSIN OCCURRENCE AND TOXICITY}

Cylindrospermopsin (CYN) is an alkaloid toxin produced by several filamentous cyanobacteria including Aphanizomenon ovalisporum (hereafter Aphanizomenon), Cylindrospermopsis raciborskii, Oscillatoria sp. PCC 6506, Anabaena bergii, Umezkia nathans, Aphanizomenon flos-aquae, and others (Banker et al., 1997; Kaebernick and Neilan, 2001; Schembri et al., 2001; Preussel et al., 2006; Mazmouz et al., 2010). CYN was shown to accumulate in the environment (Kinnear, 2010) and inhibit protein and glutathione synthesis leading to cell death (Runnegar and Lu, 1994; Runnegar et al., 1995, 2002; Froscio et al., 2001; Metcalf et al., 2004). Effects of genotoxicity and on cholesterol levels have also been reported (Humpage et al., 2000, 2005; Shen et al., 2002; Reisner et al., 2004). Activity of cytochrome P450 enzyme system is apparently essential for the development of CYN toxicity (Runnegar et al., 1995). Damage to DNA (Straser et al., 2011) and carcinogenic activity were also suggested (Humpage et al., 2000; Murphy and Thomas, 2001). The role of specific residues essential for CYN toxicity is emerging in that the uracil moiety and the hydroxyl at position C7 are essential (Banker et al., 2001).

Due to its practical importance, emphasis was placed on abiotic conditions under which blooms of CYN-forming organisms may occur (Hadas et al., 1999, 2002; Burford and Davis, 2011; De Figueiredo et al., 2011) and to assessment of the effect of abiotic parameters on CYN production under field and laboratory conditions such as S and P limiting conditions (Bacsi et al., 2006). A comprehensive description of the many excellent studies on bloom conditions in various water bodies is beyond the scope of this paper. One example is the case of Aphanizomenon population in Lake Kinneret that showed close agreement between the optimal conditions for its growth in the laboratory and those which occurred during its bloom in 1994 (Hadas et al., 2002). An important aspect is the size of the inoculum; formation of akinetes; and their germination thereby raising the new population is poorly understood and requires further research (Sukenik et al., 2007). Maximal CYN formation in C. raciborskii is observed under light intensity higher than required for optimal growth (Dyble et al., 2006), suggesting that the redox state of the cells is involved. Apparently the status of the C. raciborskii culture, logarithmic, or stationary, is also critical to the rate of CYN formation. In both diazotrophic and nitrate supplied log phase cultures, CYN accumulation is linear with the growth rate but decoupling between the two parameters is observed at stationary phase (Hawkins et al., 2001). Similarly, differential effects of temperature on growth and CYN production in various $C$. raciborskii strains were observed (Saker and Griffiths, 2000). Taken together, the bulk of the data indicate that little is known about the cellular mechanisms involved in the regulation of CYN formation 
and their interaction with the abiotic conditions experienced by the cells. Furthermore, as in the case of microcystin discussed above, comparison of published data is rather difficult because of lack of information on the exact conditions and the very different conditions in field and laboratory experiments.

\section{THE aoa/cyr GENE CLUSTERS AND CYN BIOSYNTHESIS}

The mechanism of CYN biosynthesis was partly resolved by following production in $C$. raciborskii cultures that were supplemented with stable ${ }^{13} \mathrm{C},{ }^{18} \mathrm{O},{ }^{15} \mathrm{~N}$, and ${ }^{3} \mathrm{H}$ isotopes, suggesting that five molecules of acetate are catalytically condensed by a polyketide-synthase (PKS) to form the carbon skeleton of CYN. Two other carbons and one of the nitrogen atoms of the guanidine moiety are probably donated by glycine. Guanidinoacetic acid was proposed as a source for two nitrogen atoms of the guanidino moiety used as a starter unit that initiates the biosynthetic process. The guanidinoacetic acid is probably formed by amidination of glycine by amidinotransferase but the exact donor of the other $\mathrm{N}$ atoms in the guanidino moiety, most likely arginine, has not been resolved (Burgoyne et al., 2000; Murphy and Thomas, 2001; Shalev-Alon et al., 2002; Pearson et al., 2010). Following the recognition that PKS and amidinotransferase are involved, Shalev-Alon et al. (2002) identified a genomic region in Aphanizomenon likely involved in CYN biosynthesis; recognition of a similar genomic region in $C$. raciborskii (Mihali et al., 2008) and Oscillatoria sp. strain PCC 6506 (Mazmouz et al., 2010) followed (Figure 2). It should be noted, however, that we are missing unequivocal evidence that the aoa/cyr gene clusters in these organisms are engaged in CYN biosynthesis. Although genes essential for CYN biosynthesis are present in these clusters, since these organisms are, so far, not amenable to genetic manipulations it was not possible to inactivate these genes and thereby provide a critical evidence that we have been seeking.

Support to the notion that the aoa/cyr gene cluster is indeed involved in CYN biosynthesis rests on the observation that a sulfotransferase-encoding gene essential for CYN synthesis, cyrJ, is present only in CYN-producing C. raciborskii strains (Mihali et al., 2008; Alster et al., 2010). Similarly, cyrJ is detected in four CYN-producing Oscillatoria strains but lacking in a nonCYN-producing strain (Mazmouz et al., 2010). Finally, non-toxic Aphanizomenon isolated from Lake Kinneret possess aoaA and aoaC but is missing aoaJ (Ballot et al., 2011).

Following the identification of the gene clusters putatively involved in CYN biosynthesis (Figure 2 and below), an attractive (and most likely) scheme of the cascade of events leading to CYN formation was proposed (Mihali et al., 2008; Pearson et al., 2010; the reader is referred to these publications for a comprehensive discussion of the proposed scheme). However, decisive evidence that this is indeed the case must await biochemical confirmation. Furthermore, the proposed scheme does not account for the formation of two CYN analogs, 7-deoxycylindrospermopsin (7deoxy-CYN) and 7-epicylindrospermopsin (7-epi-CYN) whose relative abundance varies in different cyanobacterial species (see Mazmouz et al., 2011), suggesting alterations in the activity and regulation of various steps in CYN production. It was suggested that CyrI, a 2-oxoglutarate-dependent iron oxygenase performs the last step of CYN biosynthesis from 7-deoxy-CYN (Mazmouz et al., 2011). These authors raised the possibility that a relaxed

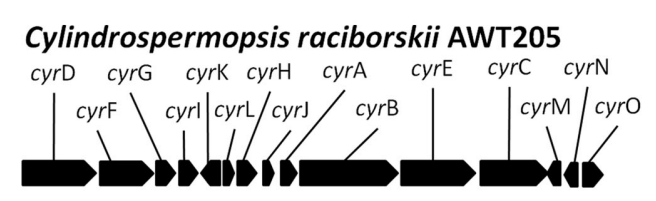

Oscillatoria sp. strain PCC 6506

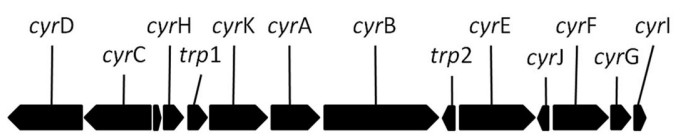

Aphanizomenon sp. $10 \mathrm{E} 6$

aoa $\mathrm{E}$ aoa $\mathrm{B}$ aoaC aoaD aoaG aoak aoaJ

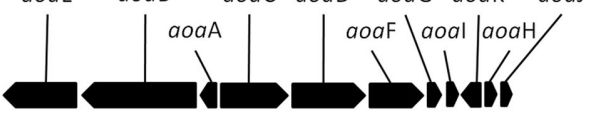

Aphanizomenon ovalisporum ILC146

aoa aoaB aoaA aoaD aoaF aoal aoak trp1 trp2 XRETF

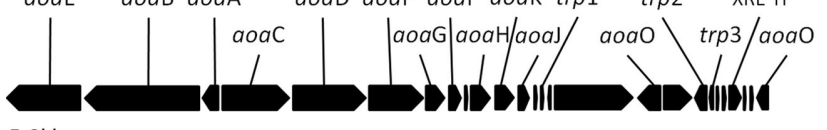

5.0kbp

FIGURE 2 | The aoa/cyr clusters putatively involved in cylindrospermopsin biosynthesis in four cyanobacterial species. The scheme was constructed based on data for Cylindrospermopsis raciborskii (Mihali et al., 2008), Oscillatoria sp. PCC 6506C (Mazmouz et al., 2010), Aphanizomenon strain 10E6 (Accession Number, WOS, 000281239600017; Stuken and Jakobsen, 2010), and Aphanizomenon ovalisporum strain ILC146 (draft, yet unpublished sequence). Open reading frames without designation represent hypothetical proteins. Note the transposase (trp) genes and transcription factor (XRETF) in the sequence of Aphanizomenon strain ILC146. The high sequence similarity between genes in the four species suggests a common ancestor but the significant differences in gene organization may indicate lateral gene transfers and transposases involvement (see text). Note that despite the presence of genes essential for CYN biosynthesis, we are still missing experimental evidence for the role of this cluster.

stereospecificity of CyrI produces both stereoisomers at position 7 . Alternatively, an unidentified hydroxylase produces the 7-epi-CYN from 7-deoxy-CYN. The levels of CyrI or its activity in various CYN-producing cyanobacteria should be examined to account for the variability in the abundance of 7-deoxy-CYN compared to CYN; 7-deoxy-CYN is a minor product in C. raciborskii and Raphidiopsis curvata (Li et al., 2001) but a major one in Lyngbya wollei (Seifert et al., 2007). On the other hand 7-epi-CYN was detected only in Aphanizomenon in small quantities.

Figure 2 shows the genomic organization of the aoa/cyr in four CYN-producing cyanobacteria. In the absence of a detailed phylogenetic analysis it is hard to assess the development of these clusters but high similarity between the genes does indicate that they are evolutionarily related, possibly from a common ancestor, and that an horizontal gene transfer was involved (Stuken and Jakobsen, 2010). The differences in the gene organization clearly indicate divergence from this ancestor; shuffling of the aoa/cyr genes is substantial. The two Aphanizomenon clusters are quite similar but with two main exceptions. Two aoaO genes can be identified in strain ILC146 (draft, yet unpublished sequence) but we could not detect it in strain 10E6 (Accession Number, WOS, 000281239600017; 
Stuken and Jakobsen, 2010). Altogether, the role of aoaO/cyrO in CYN production, if any, is not clear due to its low homology to other genes in the data bases. Again, a genetic approach could resolve this question. Compared with strain ILC146, the region of aoaH-K underwent reorganization in strain 10E6 with the aoaK encoded on the opposite strand and precedes aoaH. The presence of several transposase encoding genes is noted and they may be involved in the reorganizations.

\section{REGULATION OF TRANSCRIPTION}

Following the identification of the genomic regions putatively involved in CYN biosynthesis in Aphanizomenon (Shalev-Alon et al., 2002), C. raciborskii (see Neilan et al., 2008), and Oscillatoria strain PCC 6506 (Mazmouz et al., 2010), it became possible to study their regulation. In both Aphanizomenon species but not in C. raciborskii and Oscillatoria sp. (Figure 2) the amidinotransferase and polyketide-synthase encoding genes, aoaA and aoaC, respectively, are transcribed on the reverse strands. Analysis of the genomic region between them identified two transcription start points for each of these genes, differentially expressed under nitrogen and light-stress conditions (Shalev-Alon et al., 2002) and by phosphate availability (Bar-Yosef et al., 2010). Gel shift assays and DNA affinity columns isolated a protein that specifically binds to a 150-bp DNA fragment from the region between aoaA and aoaC in Aphanizomenon ILC146 and MS/MS analyses identified similarity to AbrB in other cyanobacteria and in Bacillus sp. Comparison of the native AbrB isolated from A. ovalisporum with that obtained after cloning and over-expression of $a b r B$ in E. coli identified specific post-translational modifications in the native cyanobacterial $\mathrm{AbrB}$. This includes $\mathrm{N}$-acetylation of residue $\mathrm{T} 2$ and methylation of specific residues, which are all missing in the protein expressed in E. coli. A gene encoding a putative acetylase was identified in the draft genomic sequence of Aphanizomenon ILC146 (yet unpublished) but, as mentioned with respect to the role of aoa genes, failure to genetically modify or inactivate genes in this organism does not enable recognition of the significance of these modifications to aoaA/C expression. The exact role of these post-translational modifications to the regulation of CYN formation is yet to be established. It is worth mentioning that AbrB-like proteins were thereafter recognized in various cyanobacteria. In Synechocystis sp. PCC6803 they were implicated in the regulation of several genes belonging to inorganic carbon uptake (LiemanHurwitz et al., 2009), nitrogen metabolism and C-N regulation (Yamauchi et al., 2011), the bidirectional hydrogenase (Oliveira and Lindblad, 2008), and in iron superoxide dismutase in Nostoc sp. strain PCC 7120 (Agervald et al., 2010). However, as much as information gained from these fields may contribute to our understanding of the involvement of these AbrB-like (designated CyAbrB) in CYN formation, a comprehensive analysis is beyond the scope of the present review.

\section{THE BIOLOGICAL ROLE OF CYN}

Laboratory and field experiments revealed the biological role and function of CYN (Bar-Yosef et al., 2010). Many microorganisms, from bacteria to yeast, respond to inorganic phosphate (Pi) limitation by expressing their $\mathrm{PHO}$ regulon and excretion of alkaline phosphatase (APase) thereby enhancing the supply of Pi from organic compounds and improving their competitiveness for resources and domination. Analysis of the abundance of Aphanizomenon and APase activity in Lake Kinneret during the summers of 1994-2009 showed strong correlation between these parameters, suggesting that APase emerged from Pi-limited filaments, but closer analysis clearly indicated this was not the case (BarYosef et al., 2010). Application of enzyme labeled fluorescence (ELF) on lake samples showed APase in various organisms but not in Aphanizomenon, and staining by DAPI revealed high level of polyphosphate bodies (PPBs) in Aphanizomenon. ELF-APase signals were detected in Aphanizomenon only after it exploited the PPBs under prolonged Pi deprivation in laboratory cultures or toward the end of its natural bloom, in the autumn (Bar-Yosef et al., 2010). Aphanizomenon cultures respond to removal of external Pi by fast induction of CYN production and only part of its PHO regulon, including the high affinity Pi uptake system, PstS, and phoD, encoding an internal APase. In contrast, transcripts encoding extracellular APase and its activity were observed only after 5-7 days during which it consumes the internal Pi.

Addition of spent media from Aphanizomenon or CYN to various phytoplankton species (Chlamydomonas reinhardtii used as a model organism) led to induction of genes typically up-regulated by Pi-limitation (Bar-Yosef et al., 2010) and a large rise in the extracellular APase activity despite the presence of ample Pi in the medium. Using ELF-APase to stain mixed cultures of Aphanizomenon with Chlamydomonas or Debarya sp. showed APase in the latter two but not in Aphanizomenon. These data suggested that CYN induces the excretion of APase by other phytoplanktons in the water body. Aphanizomenon can then compete for the Pi released consequent to APase activity from other organisms. Apparently Aphanizomenon does it quite successfully, grows rapidly, and dominates in the seasonal bloom. CYN is used to "enslave" other organisms to fulfill the Pi demands of the "toxic" strains. It explains the observed rise in APase activity in the water body during the early phase of Aphanizomenon bloom and reveals a mechanism whereby it can form massive blooms despite limiting Pi conditions.

Noticeably, the response of target organisms to Aphanizomenon spent medium was greater than observed following application of purified CYN, although its concentration in the used media was considerably smaller. This suggests a synergistic involvement of other secondary metabolites in the used media, the nature of which is not known. It resembles the stronger induction of $m c y$ genes in Microcystis sp. by its own spent medium rather than by isolated microcystin, discussed above.

Naturally we expect other CYN producers such as $C$. raciborskii to induce APase in other organisms. Lack of ELF-APase staining in lake samples of Anabaena sp., Planktothrix sp., and Planktolyngbya sp. (Rengefors et al., 2003) and delayed APase secretion in Pi-deprived Trichodesmium sp. (Orchard et al., 2009) may indicate similar capabilities in other cyanobacterial lineages that are not known to produce CYN.

Finally, there are numerous reports over the last decade showing a significant rise in the abundance of toxic filamentous $\mathrm{N}_{2}$ fixing cyanobacteria in freshwater bodies (See Sukenik et al., this issue). The reason is not known, particularly as it occurs simultaneously with intensive efforts of lake management authorities to reduce 
nutrient inflow from the watershed. The rise in cyanobacterial abundance has been attributed to various causes, including global warming, but in view of the role attributed to CYN we raise an alternative possibility that superior competitiveness for Pi enables these organisms to flourish in such lakes. In terms of competitiveness, it is worth mentioning that $\mathrm{N}$ allocation to produce CYN is cheaper for the cells than APase secretion (Bar-Yosef et al., 2010).

\section{OUTLOOK: THE MAIN OPEN QUESTIONS}

Here we focused on the biological role of two cyanobacterial toxins, microcystin and cylindrospermopsin, but many open questions need to be resolved. We proposed external and internal roles of microcystin and presented experimental evidence to support our view. Given the phylogenetic analysis that revealed that $m c y$ (and $s x t$ ) are ancient but were lost in most of the present-day cyanobacterial strains, we raise the question what, if any, fulfills these biological roles in the other cyanobacterial strains lacking microcystin. What were the evolutional drivers that led to the deletion of mcy genes from most strains? We are missing an experiment whereby spent media, and/or supernatant from broken cells of one of the strains for which genetic information and tools (such as microarray) are available, will be applied to its own population. This will be followed by an analysis of the transcript abundances. Perhaps some other secondary metabolites perform these roles, as do micropeptin and microginin for the infochemical task in Microcystis. Furthermore, given the advantage of toxic over non-toxic Microcystis strains in growth competition experiments, why do we often find them inhabiting the same habitat, indoor as well as outdoor? Is it possible that while saving the resources necessary to produce microcystin, the non-toxic strains use microcystin produced by the toxic ones? What is in fact the role of $\mathrm{McyH}$, which shows homology to $\mathrm{ABC}$ transporters but its inactivation blocks microcystin biosynthesis? Does it, like some

\section{REFERENCES}

Abraham, E. R. (1998). The generation of plankton patchiness by turbulent stirring. Nature 391, 577-580.

Agervald, A., Baebprasert, W., Zhang, X. H., Incharoensakdi, A., Lindblad, P., and Stensjo, K. (2010). The CyAbrB transcription factor CalA regulates the iron superoxide dismutase in Nostoc sp. strain PCC 7120. Environ. Microbiol. 12, 2826-2837.

Alexova, R., Haynes, P. A., Ferrari, B. C., and Neilan, B. A. (2011). Comparative protein expression in different strains of the bloom-forming cyanobacterium Microcystis aeruginosa. Mol. Cell. Proteomics 10, M110 003749.

Alfonso, M., Perewoska, I., and Kirilovsky, D. (2001). Redox control of ntcA gene expression in Synechocystis sp. PCC 6803: nitrogen availability and electron transport regulate the levels of the NtcA protein. Plant Physiol. 125, 969-981.

Alster, A., Kaplan-Levy, R. N., Sukenik, A., and Zohary, T. (2010). Morphology and phylogeny

other transporters, serve as the sensor for microcystin presence in the environment?

For CYN, with the emergence of more aoa/cyr sequences, it is becoming possible to perform a phylogenetic analysis for these gene clusters as well but the main task is to develop the means to make at least one of the CYN-producing strains amenable to genetic manipulations. We are still missing experimental evidence that this gene cluster is involved in CYN production. What are the mechanisms whereby presence of CYN induces the PHO regulon in other phytoplankton species even in the presence of ample Pi externally? What are the mechanisms enabling the differential expression of some of the $\mathrm{PHO}$ regulon genes in Aphanizomenon whereby external alkaline phosphatase is blocked as long as internal $\mathrm{P}$ is available in the form of polyphosphate bodies? What is the nature of the other components in the spent medium from Aphanizomenon that act synergistically with CYN? Is this ability to improve its own $\mathrm{P}$ supply by enslaving other organisms unique to Aphanizomenon? Can a similar mechanism be found in other organisms for $\mathrm{P}$ or other nutrients? These are just some of the open questions ensuring an exciting research period ahead of us.

\section{ACKNOWLEDGMENTS}

We thank Dr. R. Reinhardt and Dr. M. Kube from Max Planck Institute for Molecular Genetics, Berlin, for their guidance and support with the molecular analysis of $A$. ovalisporum genome. Research in our laboratories is supported by grants from the Israel Science Foundation to Aaron Kaplan; Israeli Science and Technology Ministry (MOST) to Aaron Kaplan and Assaf Sukenik; the German Research Foundation (Di910/3-1) to Elke Dittmann; the Hebrew University of Jerusalem to Aaron Kaplan; the Israel Water Authority to Assaf Sukenik and Aaron Kaplan; the Yohai BenNoon Foundation to Moshe Harel; and by the EU-NEST program to Assaf Sukenik, Ora Hadas, and Ruth N. Kaplan-Levy.

C. (2011). Occurrence of noncylindrospermopsin-producing Aphanizomenon ovalisporum and Anabaena bergii in Lake Kinneret (Israel). J. Plankton Res. 33, 1736-1746.

Banker, R., Carmeli, S., Hadas, O., Teltsch, B., Porat, R., and Sukenik, A. (1997). Identification of cylindrospermopsin in the cyanobacterium Aphanizomenon ovalisporum (Cyanophyceae) isolated from Lake Kinneret, Israel. J. Phycol. 33, 613-616.

Banker, R., Carmeli, S., Werman, M., Teltsch, B., Porat, R., and Sukenik, A. (2001). Uracil moiety is required for toxicity of the cyanobacterial hepatotoxin cylindrospermopsin. J. Toxicol. Environ. Health 62 , 281-288.

Bar-Yosef, Y., Sukenik, A., Hadas, O., Viner-Mozzini, Y., and Kaplan, A. (2010). Enslavement in the water body by toxic Aphanizomenon ovalisporum, inducing alkaline phosphatase in phytoplanktons. Curr. Biol. 20, 1557-1561.
Botes, D. P., Tuinman, A. A., Wessels, P. L., Viljoen, C. C., Kruger, H., Williams, D. H., Santikarn, S., Smith, R. J., and Hammond, S. J. (1984). The structure of cyanoginosin-LA, a cyclic heptapeptide toxin from the cyanobacterium Microcystis aeruginosa. J. Chem. Soc. Perkin Trans. I 1, 2311-2318.

Burford, M. A., and Davis, T. W. (2011). Physical and chemical processes promoting dominance of the toxic cyanobacterium Cylindrospermopsis raciborskii. Chin. J. Oceanol. Limnol. 29, 883-891.

Burgoyne, D. L., Hemscheidt, T. K., Moore, R. E., and Runnegar, M. T. C. (2000). Biosynthesis of cylindrospermopsin, J. Org. Chem. 65, 152-156.

Carmichael, W. W. (1997). The cyanotoxins. Adv. Bot. Res. 9, 211-256.

Christiansen, G., Fastner, J., Erhard, M., Borner, T., and Dittmann, E. (2003). Microcystin biosynthesis in Planktothrix: genes, evolution, and manipulation. J. Bacteriol. 185, 564-572. 
Christiansen, G., Molitor, C., Philmus, B., and Kurmayer, R. (2008). Nontoxic strains of cyanobacteria are the result of major gene deletion events induced by a transposable element. Mol. Biol. Evol. 25, 1695-1704.

De Figueiredo, D. R., Goncalves, A. M. M., Castro, B. B., Goncalves, F., Pereira, M. J., and Correia, A. (2011). Differential inter- and intra-specific responses of Aphanizomenon strains to nutrient limitation and algal growth inhibition. J. Plankton Res. 33, 1606-1616.

Dittmann, E., Neilan, B. A., and Borner, T. (2001). Molecular biology of peptide and polyketide biosynthesis in cyanobacteria. Appl. Microbiol. Biotechnol. 57, 467-473.

Dittmann, E., Neilan, B. A., Erhard, M., von Doehren, H., and Boerner, T. (1997). Insertional mutagenesis of a peptide synthetase gene that is responsible for hepatotoxin production in the cyanobacterium Microcystis aeruginosa PCC 7806. Mol. Microbiol. 26, 779-787.

Dittmann, E., and Wiegand, C. (2006). Cyanobacterial toxins - occurrence, biosynthesis and impact on human affairs. Mol. Nutr. Food Res. 50, 7-17.

Dyble, J., Tester, P. A., and Litaker, R. W. (2006). Effects of light intensity on cylindrospermopsin production in the cyanobacterial HAB species Cylindrospermopsis raciborskii. Afr. J. Mar. Sci. 28, 309-312.

Dziallas, C., and Grossart, H. P. (2011). Temperature and biotic factors influence bacterial communities associated with the cyanobacterium Microcystis sp. Environ. Microbiol. 13, 1632-1641.

Engene, N., Choi, H., Esquenazi, E., Rottacker, E. C., Ellisman, M. H., Dorrestein, P. C., and Gerwick, W. H. (2011). Underestimated biodiversity as a major explanation for the perceived rich secondary metabolite capacity of the cyanobacterial genus Lyngbya. Environ. Microbiol. 13, 1601-1610.

Fastner, J., Erhard, M., and von Dohren, H. (2001). Determination of oligopeptide diversity within a natural population of Microcystis spp. (cyanobacteria) by typing single colonies by matrix-assisted laser desorption ionization-time of flight mass spectrometry. Appl. Environ. Microbiol. 67, 5069-5076.

Froscio, S. M., Humpage, A. R., Burcham, P. C., and Falconer, I. R. (2001). Cell-free protein synthesis inhibition assay for the cyanobacterial toxin cylindrospermopsin. Environ. Toxicol. 16, 408-412.
Gerbersdorf, S. U. (2006). An advanced technique for immuno-labelling of microcystins in cryosectioned cells of Microcystis aeruginosa PCC 7806 (cyanobacteria), implementations of an experiment with varying light scenarios and culture densities. Toxicon 47, 218-228.

Ginn, H. P., Pearson, L. A., and Neilan, B. A. (2010). NtcA from Microcystis aeruginosa PCC 7806 is autoregulatory and binds to the microcystin promoter. Appl. Environ. Microbiol. 76, 4362-4368.

Griffiths, D. J., and Saker, M. L. (2003). The palm island mystery disease 20 years on: a review of research on the cyanotoxin cylindrospermopsin. Environ. Toxicol. 18, 78-93.

Hadas, O., Pinkas, R., Delphine, E., Vardi, A., Kaplan, A., and Sukenik, A. (1999). Limnological and ecophysiological aspects of Aphanizomenon ovalisporum bloom in Lake Kinneret. J. Plankton Res. 21, 1439-1453.

Hadas, O., Pinkas, R., MalinskyRoshansky, N., Shalev-Alon, G., Delphine, E., Berner, T., Sukenik, A., and Kaplan, A. (2002). Physiological variables determined under laboratory conditions may explain the bloom of Aphanizomenon ovalisporum in Lake Kinneret. Eur. J. Phycol. 37, 259-267.

Hawkins, P. R., Putt, E., Falconer, I., and Humpage, A. (2001). Phenotypical variation in a toxic strain of the phytoplankter, Cylindrospermopsis raciborskii (Nostocales, Cyanophyceae) during batch culture. Environ. Toxicol. 16, 460-467.

Hesse, K., Dittmann, E., and Boerner, T. (2001). Consequence of impaired microcystin production for lightdependent growth and pigmentation of Microcystis aeruginosa PCC 7806. FEMS Microbiol. Ecol. 37, 39-43.

Humpage, A. R., Fenech, M., Thomas, P., and Falconer, I. R. (2000). Micronucleus induction and chromosome loss in transformed human white cells indicate clastogenic and aneugenic action of the cyanobacterial toxin, cylindrospermopsin. Mutat. Res. 472, 155-161.

Humpage, A. R., Fontaine, F., Froscio, S., Burcham, P., and Falconer, I. R. (2005). Cylindrospermopsin genotoxicity and cytotoxicity: role of cytochrome P-450 and oxidative stress. J. Toxicol. Environ. Health A 68, 739-753.

Jahnichen, S., Ihle, T., Petzoldt, T., and Benndorf, J. (2007). Impact of inorganic carbon availability on microcystin production by Microcystis aeruginosa PCC 7806. Appl. Environ. Microbiol. 73, 6994-7002.

Jochimsen, E. M., Carmichael, W. W. An, J. S., Cardo, D. M., Cookson, S. T., Holmes, C. E., Antunes, M. B., de Melo Filho, D. A., Lyra, T. M., and Barreto, V. S. (1998). Liver failure and death after exposure to microcystins at a hemodialysis center in Brazil. N. Engl. J. Med. 338, 873-878.

Jones, A. C., Monroe, E. A., Podell, S. Hess, W. R., Klages, S., Esquenazi, E., Niessen, S., Hoover, H., Rothmann, M., Lasken, R. S., Yates, J. R. Reinhardt, R., Kube, M., Burkart, M., Allen, E. E., Dorrestein, P. C., Gerwick, W. H., and Gerwick, L. (2011). Genomic insights into the physiology and ecology of the marine filamentous cyanobacterium Lyngbya majuscula. Proc. Natl. Acad. Sci. U.S.A. 108, 8815-8820.

Kaebernick, M., Dittmann, E., Boerner, T., and Neilan, B. A. (2002). Multiple alternate transcripts direct the biosynthesis of microcystin, a cyanobacterial nonribosomal peptide. Appl. Environ. Microbiol. 68 449-455.

Kaebernick, M., Neilan, B. A., Boerner, T., and Dittmann, E. (2000). Light and the transcriptional response of the microcystin biosynthetic gene cluster. Appl. Environ. Microbiol. 66, 3387-3392.

Kaebernick, M., and Neilan, B. A. (2001). Ecological and molecular investigations of cyanotoxin production. FEMS Microbiol. Ecol. 35, 1-9.

Kehr, J. C., Zilliges, Y., Springer, A., Disney, M. D., Ratner, D. D., Bouchier, C., Seeberger, P. H., de Marsac, N. T. and Dittmann, E. (2006). A mannan binding lectin is involved in cell-cell attachment in a toxic strain of Microcystis aeruginosa. Mol. Microbiol. 59, 893-906.

Kinnear, S. (2010). Cylindrospermopsin: a decade of progress on bioaccumulation research. Mar. Drugs 8, 542-564.

Li, R., Carmichael, W. W., Brittain, S., Eaglesham, G. K., Shaw, G. R., Mahakhant, A., Noparatnaraporn, N., Yongmanitchai, W., Kaya, K., and Watanabe, M. M. (2001). Isolation and identification of the cyanotoxin cylindrospermopsin and deoxy-cylindrospermopsin from a Thailand strain of Cylindrospermopsis raciborskii (cyanobacteria). Toxicon 39, 973-980.

Lieman-Hurwitz, J., Haimovich, M., Shalev-Malul, G., Ishii, A., Hihara, Y., Gaathon, A., Lebendiker, M., and Kaplan, A. (2009). A cyanobacterial AbrB-like protein affects the apparent photosynthetic affinity for $\mathrm{CO}_{2}$ by modulating low- $\mathrm{CO}_{2}$ induced gene expression. Environ. Microbiol. 11, 927-936.

Liu, L., and Rein, K. S. (2010). New peptides isolated from lyngbya species: a review. Mar. Drugs 8, 1817-1837.

Long, B. M., Jones, G. J., and Orr, P. T. (2001). Cellular microcystin content in N-limited Microcystis aeruginosa can be predicted from growth rate. Appl. Environ. Microbiol. 67, 278-283.

Lopez-Gomollon, S., Hernandez, J. A., Pellicer, S., Angarica, V. E., Peleato, M. L., and Fillat, M. F. (2007). Crosstalk between iron and nitrogen regulatory networks in Anabaena (Nostoc) sp. PCC 7120, identification of overlapping genes in FurA and NtcA regulons. J. Mol. Biol. 374, 267-281.

Lukac, M., and Aegerter, R. (1993). Influence of trace-metals on growth and toxin production of Microcystis aeruginosa. Toxicon 31, 293-305.

Martin-Luna, B., Sevilla, E., Hernandez, J. A., Bes, M. T., Fillat, M. F., and Peleato, M. L. (2006). Fur from Microcystis aeruginosa binds in vitro promoter regions of the microcystin biosynthesis gene cluster. Phytochemistry 67, 876-881.

Mazmouz, R., Chapuis-Hugon, F., Mann, S., Pichon, V., Mejean, A. and Ploux, O. (2010). Biosynthesis of cylindrospermopsin and 7epicylindrospermopsin in Oscillatoria sp. strain PCC 6506, Identification of the cyr gene cluster and toxin analysis. Appl. Environ. Microbiol. 76, 4943-4949.

Mazmouz, R., Chapuis-Hugon, F., Pichon, V., Mejean, A., and Ploux, O. (2011). The last step of the biosynthesis of the cyanotoxins cylindrospermopsin and 7-epicylindrospermopsin is catalysed by CyrI, a 2-oxoglutarate-dependent iron oxygenase. Chembiochem 12, 858-862.

Mejean, A., Mazmouz, R., Mann, S., Calteau, A., Medigue, C., and Ploux, O. (2010). The genome sequence of the cyanobacterium Oscillatoria sp. PCC 6506 reveals several gene clusters responsible for the biosynthesis of toxins and secondary metabolites. J. Bacteriol. 192, 5264-5265.

Metcalf, J. S., Barakate, A., and Codd, G. A. (2004). Inhibition of plant protein synthesis by the cyanobacterial hepatotoxin, cylindrospermopsin. FEMS Microbiol. Lett. 235, 125-129.

Mihali, T. K., Kellmann, R., Muenchhoff, J., Barrow, K. D., and Neilan, B. A. (2008). Characterization of the 
gene cluster responsible for cylindrospermopsin biosynthesis. Appl. Environ. Microbiol. 74, 716-722.

Moffitt, M. C., and Neilan, B. A. (2004). Characterization of the nodularin synthetase gene cluster and proposed theory of the evolution of cyanobacterial hepatotoxins. Appl. Environ. Microbiol. 70, 6353-6362.

Murphy, P. J., and Thomas, C. W. (2001). The synthesis and biological activity of the marine metabolite cylindrospermopsin. Chem. Soc. Rev. 30, 303-312.

Murray, S. A., Mihali, T. K., and Neilan, B. A. (2011). Extraordinary conservation, gene loss, and positive selection in the evolution of an ancient neurotoxin. Mol. Biol. Evol. 28, 1173-1182.

Neilan, B. A., Pearson, L. A., Moffitt, M. C., Mihali, K. T., Kaebemick, M., Kellmann, R., and Pomati, F. (2008). "The genetics and genomics of cyanobacterial toxicity," in Cyanobacterial Harmful Algal Blooms, State of the Science and Research Needs, Vol. 619, ed. H. K Hudnell (New York: Springer), 417-452.

Nishizawa, T., Asayama, M., Fujii, K., Harada, K., and Shirai, M. (1999). Genetic analysis of the peptide synthetase genes for a cyclic heptapeptide microcystin in Microcystis spp. J. Biochem. 126, 520-529.

Nishizawa, T., Ueda, A., Asayama, M., Fujii, K., Harada, K., Ochi, K., and Shirai, M. (2000). Polyketide synthase gene coupled to the peptide synthetase module involved in the biosynthesis of the cyclic heptapeptide microcystin. J. Biochem. 127, 779-789.

Ogawa, Y. (1988). Net increase rates and dynamics of phytoplankton populations under hypereutrophic and eutrophic conditions. Jpn. J. Limnol. 49, 261-268.

Oliveira, P., and Lindblad, P. (2008). An AbrB-like protein regulates the expression of the bidirectional hydrogenase in Synechocystis sp. strain PCC 6803. J. Bacteriol. 190, 1011-1019.

Orchard, E. D., Webb, E. A., and Dyhrman, S. T. (2009). Molecular analysis of the phosphorus starvation response in Trichodesmium spp. Environ. Microbiol. 11, 2400-2411.

Orr, P. T., and Jones, G. J. (1998). Relationship between microcystin production and cell division rates in nitrogen-limited Microcystis aeruginosa cultures. Limnol. Oceanogr. 43, 1604-1614.
Paerl, H. W., and Huisman, J. (2009). Climate change, a catalyst for global expansion of harmful cyanobacterial blooms. Environ. Microbiol. Rep. 1, 27-37.

Pearson, L., Hisbergues, M., Dittmann, E., Boerner, T., and Neilan, B. A. (2004). Inactivation of an $\mathrm{ABC}$ transporter, $\mathrm{McyH}$, results in loss of microcystin production in the cyanobacterium Microcystis aeruginosa PCC 7806. Appl. Environ. Microbiol. 70, 6370-6378.

Pearson, L., Mihali, T., Moffitt, M., Kellmann, R., and Neilan, B. (2010). On the chemistry, toxicology and genetics of the cyanobacterial toxins, microcystin, nodularin, saxitoxin and cylindrospermopsin. Mar. Drugs 8, 1650-1680.

Pflugmacher, S. (2002). Possible allelopathic effects of cyanotoxins, with reference to microcystin-LR, in aquatic ecosystems. Environ. Toxicol. 17, 407-413.

Preussel, K., Stuken, A., Wiedner, C., Chorus, I., and Fastner, J. (2006). First report on cylindrospermopsin producing Aphanizomenon flos-aquae (Cyanobacteria) isolated from two German lakes. Toxicon 47, 156-162.

Rantala, A., Fewer, D. P., Hisbergues, M., Rouhiainen, L., Vaitomaa, J., Borner, T., and Sivonen, K. (2004). Phylogenetic evidence for the early evolution of microcystin synthesis. Proc. Natl. Acad. Sci. U.S.A. 101, 568-573.

Rapala, J., Sivonen, K., Lyra, C., and Niemela, S.-I. (1997). Variation of microcystins, cyanobacterial hepatotoxins, in Anabaena spp. as a function of growth stimuli. Appl. Environ. Microbiol. 63, 2206-2212.

Reisner, M., Carmeli, S., Werman, M., and Sukenik, A. (2004). The cyanobacterial toxin cylindrospermopsin inhibits pyrimidine nucleotide synthesis and alters cholesterol distribution in mice. Toxicol. Sci. 82, 620-627.

Rengefors, K., Ruttenberg, K. C., Haupert, C. L., Taylor, C., Howes, B. L., and Anderson, D. M. (2003). Experimental investigation of taxonspecific response of alkaline phosphatase activity in natural freshwater phytoplankton. Limnol. Oceanogr. 48, 1167-1175.

Rodelas, B., Lithgow, J. K., WisniewskiDye, F., Hardman, A., Wilkinson, A., Economou, A., Williams, P., and Downie, J. A. (1999). Analysis of quorum-sensing-dependent control of rhizosphere-expressed ( $r h i$ ) genes in Rhizobium leguminosarum bv. viciae. J. Bacteriol. 181, 3816-3823.
Rohrlack, T., Dittmann, E., Boerner, T., and Christoffersen, K. (2001). Effects of cell-bound microcystins on survival and feeding of Daphnia spp. Appl. Environ. Microbiol. 67 3523-3529.

Rohrlack, T., Dittmann, E., Henning, M., Borner, T., and Kohl, J. G. (1999). Role of microcystins in poisoning and food ingestion inhibition of Daphnia galeata caused by the cyanobacterium Microcystis aeruginosa. Appl. Environ. Microbiol. 65, 737-739.

Rouhiainen, L., Vakkilainen, T., Siemer, B. L., Buikema, W., Haselkorn, R., and Sivonen, K. (2004). Genes coding for hepatotoxic heptapeptides (microcystins) in the cyanobacterium Anabaena strain 90. Appl. Environ. Microbiol. 70, 686-692.

Runnegar, M., and Lu, S. (1994). The role of glutathione (Gsh) in the hepatotoxicity caused by the cyanobacterial alkaloid cylindrospermopsin (Cy). FASEB J. 8, A419.

Runnegar, M. T., Kong, S. M., Zhong, Y. Z., and Lu, S. C. (1995). Inhibition of reduced glutathione synthesis by cyanobacterial alkaloid cylindrospermopsin in cultured rat hepatocytes. Biochem. Pharmacol. 49, 219-225.

Runnegar, M. T., Xie, C. Y., Snider, B. B., Wallace, G. A., Weinreb, S. M., and Kuhlenkamp, J. (2002). In vitro hepatotoxicity of the cyanobacterial alkaloid cylindrospermopsin and related synthetic analogues. Toxicol. Sci. 67, 81-87.

Saker, M. L., and Griffiths, D. J. (2000). The effect of temperature on growth and cylindrospermopsin content of seven isolates of Cylindrospermopsis raciborskii (Nostocales, Cyanophyceae) from water bodies in northern Australia. Phycologia 39, 349-354.

Schatz, D., Keren, Y., Hadas, O. Carmeli, S., Sukenik, A., and Kaplan, A. (2005). Ecological implications of the emergence of non-toxic subcultures from toxic Microcystis strains. Environ. Microbiol. 7, 798-805.

Schatz, D., Keren, Y., Vardi, A., Sukenik, A., Carmeli, S., Boerner, T., Dittmann, E., and Kaplan, A. (2007). Towards clarification of the biological role of microcystins, a family of cyanobacterial toxins. Environ. Microbiol. 9, 965-970.

Schembri, M. A., Neilan, B. A., and Saint, C. P. (2001). Identification of genes implicated in toxin production in the cyanobacterium Cylindrospermopsis raciborskii. Environ. Toxicol. $16,413-421$.
Seifert, M., McGregor, G., Eaglesham, G., Wickramasinghe, W., and Shaw, G. (2007). First evidence for the production of cylindrospermopsin and deoxy-cylindrospermopsin by the freshwater benthic cyanobacterium, Lyngbya wollei (Farlow ex Gomont) Speziale and Dyck. Harmful Algae 6, 73-80.

Sevilla, E., Martin-Luna, B., Vela, L., Bes, M. T., Fillat, M. F., and Peleato, M. L. (2008). Iron availability affects $m c y D$ expression and microcystinLR synthesis in Microcystis aeruginosa PCC7806. Environ. Microbiol. 10, 2476-2483.

Sevilla, E., Martin-Luna, B., Vela, L., Bes, M. T., Peleato, M. L., and Fillat, M. F. (2010). Microcystin-LR synthesis as response to nitrogen, transcriptional analysis of the $m c y D$ gene in Microcystis aeruginosa PCC780. Ecotoxicology 19, 1167-1173.

Shalev-Alon, G., Sukenik, A., Livnah, O. Schwarz, R., and Kaplan, A. (2002). A novel gene encoding amidinotransferase in the cylindrospermopsin producing cyanobacterium Aphanizomenon ovalisporum. FEMS Microbiol. Lett. 209, 87-91.

Shen, X. Y., Lam, P. K. S., Shaw, G. R., and Wickramasinghe, W. (2002). Genotoxicity investigation of a cyanobacterial toxin, cylindrospermopsin. Toxicon 40, 1499-1501.

Sivonen, K. (2008). "Emerging high throughput analyses of cyanobacterial toxins and toxic cyanobacteria," in Cyanobacterial Harmful Algal Blooms, State of the Science and Research Needs, Vol. 619, ed. H. K. Hudnell (New York: Springer), 539-557.

Sivonen, K., Carmichael, W. W., Namikoshi, M., Rinehart, K. L., Dahlem, A. M., and Niemela, S. I. (1990). Isolation and characterization of hepatotoxic microcystin homologs from the filamentous fresh-water cyanobacterium Nostoc sp. strain-152. Appl. Environ. Microbiol. 56, 2650-2657.

Sivonen, K., and Jones, G. (1999). "Cyanobacterial toxins," in Toxic Cyanobacteria in Water, eds I. Chorus and J. Bartram (London: E \& FN Spon), 41-111.

Straser, A., Filipic, M., and Zegura, B. (2011). Genotoxic effects of the cyanobacterial hepatotoxin cylindrospermopsin in the HepG2 cell line. Arch. Toxicol. 85, 1617-1626.

Straub, C., Quillardet, P., Vergalli, J., Tandeau de Marsac, N., and Humbert, J.-F. (2011). A day in the life of Microcystis aeruginosa strain PCC 7806 as revealed by a transcriptomic 
analysis. PLoS ONE 6, el6208. doi:10.1371/journal.pone.0016208

Stuken, A., and Jakobsen, K. S. (2010). The cylindrospermopsin gene cluster of Aphanizomenon sp strain 10E6, organization and recombination. Microbiology 156, 2438-2451.

Sukenik, A., Beardall, J., and Hadas, O. (2007). Photosynthetic characterization of developing and mature akinetes of Aphanizomenon ovalisporum (Cyanoprokaryota). J. Phycol. 43, 780-788.

Tillett, D., Dittmann, E., Erhard, M., von Dohren, H., Borner, T., and Neilan, B. A. (2000). Structural organization of microcystin biosynthesis in Microcystis aeruginosa PCC7806, an integrated peptide- polyketide synthetase system. Chem. Biol. 7, 753-764.

Tonk, L., Visser, P. M., Christiansen, G., Dittmann, E., Snelder, E. O., Wiedner, C., Mur, L. R., and Huisman, J. (2005). The microcystin composition of the cyanobacterium Planktothrix agardhii changes toward a more toxic variant with increasing light intensity. Appl. Environ. Microbiol. 71, 5177-5181.

Utkilen, H., and Gjolme, N. (1992). Toxin production by Microcystis aeruginosa as a function of light in continuous cultures and its ecological significance. Appl. Environ. Microbiol. 58, 1321-1325.
Van de Waal, D. B., Verspagen, J. M., Finke, J. F., Vournazou, V., Immers, A. K., Kardinaal, W. E., Tonk, L., Becker, S., Van Donk, E., Visser, P. M., and Huisman, J. (2011). Reversal in competitive dominance of a toxic versus non-toxic cyanobacterium in response to rising $\mathrm{CO}_{2}$. ISME J. 5, 1438-1450.

Vanderwesthuizen, A. J., and Eloff, J. N. (1985). Effect of temperature and light on the toxicity and growth of the blue-green-alga Microcystis aeruginosa (UV-006). Planta 163, 55-59.

Vezie, C., Rapala, J., Vaitomaa, J., Seitsonen, J., and Sivonen, K. (2002). Effect of nitrogen and phosphorus on growth of toxic and nontoxic Microcystis strains and on intracellular microcystin concentrations. Microb. Ecol. 43, 443-454.

Via-Ordorika, L., Fastner, J., Kurmayer, R., Hisbergues, M., Dittmann, E., Komarek, J., Erhard, M., and Chorus, I. (2004). Distribution of microcystin-producing and nonmicrocystin-producing Microcystis $\mathrm{sp}$ in European freshwater bodies: detection of microcystins and microcystin genes in individual colonies. Syst. Appl. Microbiol. 27, 592-602.

Walsby, A. E. (1997). Numerical integration of phytoplankton photosynthesis through time and depth in a water column. New Phytol. 136, 189-209.

Welker, M., and von Dohren, H. (2006). Cyanobacterial peptides nature's own combinatorial biosynthesis. FEMS Microbiol. Rev. 30 530-563.

Wiedner, C., Visser, P. M., Fastner, J., Metcalf, J. S., Codd, G. A., and Mur, L. R. (2003). Effects of light on the microcystin content of Microcystis strain PCC 7806. Appl. Environ. Microbiol. 69, 1475-1481.

Yamauchi, Y., Kaniya, Y., Kaneko, Y., and Hihara, Y. (2011). Physiological roles of the cyAbrB transcriptional regulator pair Sll0822 and Sll0359 in Synechocystis sp. strain PCC 6803. J. Bacteriol. 193, 3702-3709.

Zegura, B., Straser, A., and Filipic, M. (2011). Genotoxicity and potential carcinogenicity of cyanobacterial toxins - a review. Mutat. Res. 727 16-41.

Zilliges, Y., Kehr, J. C., Meissner, S., Ishida, K., Mikkat, S., Hagemann, M., Kaplan, A., Borner, T., and Dittmann, E. (2011). The cyanobacterial hepatotoxin microcystin binds to proteins andi increases the fitness of Microcystis under oxidative stress conditions. PLOS ONE 6, e17615. doi:10.1371/journal.pone. 0017615

Zilliges, Y., Kehr, J. C., Mikkat, S., Bouchier, C., de Marsac, N. T., Borner,
T., and Dittmann, E. (2008). An extracellular glycoprotein is implicated in cell-cell contacts in the toxic cyanobacterium Microcystis aeruginosa PCC 7806. J. Bacteriol. 190, 2871-2879.

Conflict of Interest Statement: The authors declare that the research was conducted in the absence of any commercial or financial relationships that could be construed as a potential conflict of interest.

Received: 21 January 2012; accepted: 23 March 2012; published online: 18 April 2012.

Citation: Kaplan A, Harel M, KaplanLevy RN, Hadas O, Sukenik $A$ and Dittmann E (2012) The languages spoken in the water body (or the biological role of cyanobacterial toxins). Front. Microbio. 3:138. doi: 10.3389/fmicb.2012.00138 This article was submitted to Frontiers in Aquatic Microbiology, a specialty of Frontiers in Microbiology.

Copyright (C) 2012 Kaplan, Harel, Kaplan-Levy, Hadas, Sukenik and Dittmann. This is an open-access article distributed under the terms of the Creative Commons Attribution Non Commercial License, which permits non-commercial use, distribution, and reproduction in other forums, provided the original authors and source are credited. 